\title{
SBB e propostas de condutas para uma pandemia que segue
}

A Sociedade Brasileira de Bioética (SBB) ${ }^{1}$, criada em fevereiro de 1995, é uma associação nacional de profissionais de diferentes formações, da área da Saúde e outras, interessadas em promover uma permanente reflexão sobre a ética e a ação em todas as áreas que envolvem as relações humanas, relação com outros animais, meio ambiente e os contextos que geram conflitos entre as áreas citadas. A entidade possui canais de comunicação com outras associações/organizações internacionais em Bioética e Direitos Humanos e mantém um periódico desde 2005 - Revista Brasileira de Bioética.

A Bioética, como nova área do conhecimento e de aplicação, teve seus primórdios nos anos de 1970 e espalhou-se a partir dos EUA para a Europa e para a América Latina. Mudanças nas abordagens, conceitos e princípios, foram observados ao longo desses anos. De uma visão chamada Principialista, com quatro princípios, encontrou-se uma abordagem mais ampla, que pode contemplar as diversas moralidades espalhadas pelo mundo. A Declaração Universal sobre Bioética e Direitos Humanos (DUBDH)², proposta pela UNESCO - Organização das Nações Unidas para a Educação, Ciência e Cultura em 2005, aprovada por unanimidade de 191 países, traz conteúdos de fundamentação e de aplicação imprescindíveis a uma avalição no campo da Bioética.

Entre os princípios de maior relevância que são levados em conta para as propostas de resolução de conflitos que envolvem, na maioria das vezes, as diferentes moralidades na sociedade, estão a dignidade humana, a autonomia, a responsabilidade social, o compartilhamento de benefícios, a equidade, a não discriminação e não-estigmatização.

Nestes meses de pandemia pelo COVID-19 (coronavírus SARS-CoV-2) mudanças significativas aconteceram na vida das pessoas e, sobretudo, nas práticas dos profissionais, dos planejadores, gestores e avaliadores da área da Saúde. Certamente este período trará mudanças para o futuro, no que se refere a condutas individuais e coletivas. 
Para os profissionais da área de Saúde, em sua maioria, que se deparavam com decisões habituais no dia-a-dia, agora se veem num ambiente macro de compromisso de pensar e agir fora dos padrões técnicos de conduta - tudo se conecta e tem reflexos. Agora sim, pensa-se fora da tranquilidade cotidiana. Tudo deve ser levado em consideração.

Para os gestores e tomadores de decisão, agora são colocados à prova os verdadeiros preceitos que regem as suas condutas nos aspectos que se relacionam, no ambiente prático cotidiano, a que escolhas fazer. Nesse ambiente prático macro, quanto, como, em que aplicar recursos financeiros e humanos.

Num país continental as decisões não são de consenso nem unânimes.

Como ser ou tentar ser menos "injusto"? A partir de que começar a pensar ou repensar para a tomada de decisão? Como se comportar e se relacionar com os outros profissionais de Saúde? Como se relacionar com a responsabilidade pessoal, profissional, privada, pública?

A SBB, após a criação de um grupo de profissionais de diversas áreas do conhecimento, em sua maioria vivenciadores da realidade, tomadores de decisão, traz para a sociedade a Recomendação n ${ }^{\circ} 01 / 2020$ - "que aborda fundamentos e aspecto éticos no enfrentamento da pandemia CIVID-19”. Alguns pontos da apresentação são especialmente interessantes para os Profissionais de Saúde Residentes e aos Médicos Residentes, pois tratam do acesso aos leitos, da insuficiência de recursos e da definição de parâmetros para a tomada de decisão.

\author{
Dr. Nilceu José Oliveira
}

Sociedade Brasileira de Bioética 
${ }^{1}$ Sociedade Brasileira de Bioética - http://www.sbbioetica.org.br/

${ }^{2}$ UNESCO. Declaração Universal sobre Bioética e Direitos Humanos. Brasília: Cátedra Unesco de Bioética/UnB; 2005. [Acesso em 10 jun 2015]. Disponível em:

http://bioetica.catedraunesco .unb.br /wp-content/ uploads/2015/05/ Declaração-

Universal-sobre-Bioética-e-Direitos-Humanos.pdf. 